\title{
The Financial Inclusion Development in Palestine
}

\author{
Fadi Hassan Shihadeh (Corresponding author) \\ College of Economic and Trade, Hunan University, Hunan, China \\ Azzam (M T) Hannon \\ College of Business Administration, American University in the Emirates \\ Dubai, United Arab Emirates
}

Xiu Hua Wang

School of Finance and Statistics, Hunan University, Hunan, China

Received: March 24, 2017 Accepted: April 10, 2017

doi:10.5296/ber.v7i1.11107 URL: https://doi.org/10.5296/ber.v7i1.11107

\begin{abstract}
This paper presents the financial inclusion development in Palestine, including the analysis and the discussion of the financial inclusion indicators and its comparison to other indicators in certain countries in the region. The indicators that were analyzed are the banking penetration and usage of banking services. We found that Palestine has achieved a remarkable improvement to enhance the financial inclusion such as branching and electronic tools, while the credits in Palestine has a limit level as same as the other MENA countries.

Keywords: Financial inclusion, Economic growth, Financial institutions, Palestine

\section{Introduction}

Individuals and firms should be incorporated into the financial system at an affordable cost. This process is called financial inclusion, which is possible when rural areas and the poor have open access (Wang and Shihadeh 2015; PMA 2014). Furthermore, financial inclusion entails the collaboration between all relevant parties. Financial inclusion discussions began in Palestine when the Palestine Monetary Authority (PMA) joined the Alliance for Financial Inclusion (AFI) in July 2010. Several programs and instructions are conducted by the PMA, urging banks to adopt, participate, and cooperate with financial supervisory institutions in the promotion of financial inclusion.
\end{abstract}




\section{Mll Macrothink}

Business and Economic Research

ISSN 2162-4860

2017, Vol. 7, No. 1

Financial inclusion prompted various research to measure financial inclusion indicators and their influence on economic development and to compare results among different countries. However, financial inclusion is a relatively new field, particularly in the Middle East and North Africa (MENA). In the context of developing countries, the main underlying problem is the provision of access and financial services to the poor at affordable cost. The perceived advantages of financial inclusion, preliminary data, and anecdotal evidence, Demirgüc-Kunt, et al.(2008) facilitated the progress of the financial inclusion from merely providing access to micro-crediting to incorporating remittances, savings, and insurance products into a broad concept . Sarma (2008) developed a model to measure financial inclusion level in countries. The study used three basic dimensions (banking penetration, availability of banking services, and usage). Bester et al., (2008) addressed that those who want to gain access to formal financial services may face problems. These difficulties include high cost, irrelevant designs of products, and failure to satisfy eligibility requirements, such as bank documents. In general, mobile banking models depend on a wide range of nontraditional agents, such as retailers, in providing cash-in and cash-out functions. Chatain et al. (2008) found that the reach of service providers is extended while low service costs are maintained.

In Pickens et al. (2009) study, it was found that the enormous success of mobile phone uptake in developing countries have been leveraged by using mobile banking models as key channels to tap new and underserved customers. In Bruhn and love (2009), the Azteca bank case is utilized to examine banking penetration policy's influence on target low-income individuals relative to economic development. In 2002, the bank included over 800 branches. On the one hand, the study showed a $1.4 \%$ increase in employment, with the average income rising to approximately 7\%; on the other hand, informal business owners rose by $7.6 \%$ because of increased branches. Beck et al. (2009) found that persons who opt out of using such services (those who volunteered to be excluded) believe that they do not need these services. Pickens (2009) addressed that approximately over one billion individuals with mobile phones have no bank accounts in 2009.

(Kumar and Mohanty 2011; Malik and Yadav 2014; Demirguc-Kunt and Klapper 2012; Gandhi 2013; World Bank 2015) measured and emphasized the financial inclusion indicators by country, such as banking penetration, banking branches per individual, ATM per individual, and POS, while comparing these indicators with those of other countries in the region, as well the policies and procedures adopted from governments and financial institutions. Demirguc-Kunt and Klapper (2012) measured financial inclusion indicators and utilized the World Bank index data on bank penetrations, insurances, savings, and loans, and mobile money of 148 countries. In formal institutions, the results affirmed that about $50 \%$ of the adults in such countries do not possess accounts, whereas this figure is $75 \%$ in the MENA region. Sarma and Jesim (2011) utilized the index developed by Sarma (2008) and confirmed that financial inclusion and development are strongly and positively correlated. The result of the study also indicated that the available infrastructure improves the financial inclusion levels. Akhtar and Pearce (2010) discussed the microfinance industry in MENA and the relationships in microfinance; regulatory structures in NGOs and financial inclusion are explained, as well as infrastructure in MENA countries and some financial inclusion 
approaches and opportunities in these countries. The study also determined that Arab countries suffer from high financial exclusion, but several initiatives were undertaken by central banks or formal institutions to enhance the role of MFIs in achieving financial inclusion. These countries include Egypt, Yemen, Morocco, and Syria. Pearce (2011) took the financial inclusion measurements in MENA and used them as indicators for other regions worldwide. The study discussed the impact of the financial crisis on financial inclusion and emphasized opportunities in Islamic microfinance. Furthermore, the research showed that in the region, five countries employed financial inclusion strategies. Results indicated that $21.3 \%$ adults possess bank accounts and that micro-crediting remains limited. Chatain et al. (2011) pointed that initiatives for financial inclusion, including mobile banking developments, in some countries are hampered by regulatory concerns that comply with proposed new regulatory models that include international financial integrity standards

Dittus and Klein (2011) addressed other factors include religious or cultural reasons, or a limited trust for formal financial institutions, such as those who experienced bank failure or those who fear to become victims of fraud. Ellison et al. (2010) pointed that customers who have access to formal financial services may withdraw from these institutions. Customers may withdraw from formal financial services for various reasons, including expenses, limited trust, inferior credit records, unmanageable spending, and improper product designs.. Clamara et al. (2014) studied the relationship between financial inclusion and socioeconomic characteristics (individual characteristics) in Peru and examined the effect of their correlation on the adoption of financial inclusion by individuals and enterprises. Low income, gender, low education level, and rural residence increase financial exclusion.

This study will use the banking penetration (access) indicator and some related factors such as branch number, ATMs, urban and rural branch distributions, branch and ATM population coverage, electronic payment cards, POSs, and banking accounts. The study also uses the usage factors such as access to formal financial institutions, savings, debts, deposit accounts, total credits, and total deposits are also considered.

\subsection{Methodology}

The development of financial inclusion indicators is analyzed. Secondary data from the Palestine Monetary Authority (PMA) annual reports, Palestinian Central Bureau of Statistics (PCBS) publications and statistics, World Bank-Global findex, World Bank researches, Central Banks of Jordan, Lebanon and Egypt, and the Association of Banks in these countries are used in the study.

\section{Analysis of Financial Inclusion Indicators}

\subsection{Banking Penetrations}

2.1.1 The total number of banks in Palestine is sixteen 16 (which are seven local banks including three Islamic, and nine foreign banks); as of 2016, the total number of the branches and offices of these banks is 309 PMA (2017). In Lebanon, the total number of banks is 53, including 1060 branches, whereas 25 banks with 1,060 branches exist in Jordan as of 2015. 


\section{Macrothink}

Business and Economic Research ISSN 2162-4860 2017, Vol. 7, No. 1

2.1.2 The number of ATMs has developed from 378 ATMs in 2011 to 622 ATMs as of 2016. While in Lebanon 1707 and in Jordan 1488 as of 2015. Figure (1) presents the development in the banking penetrations in Palestine through banks branches and ATMs from 2011 to 2016.

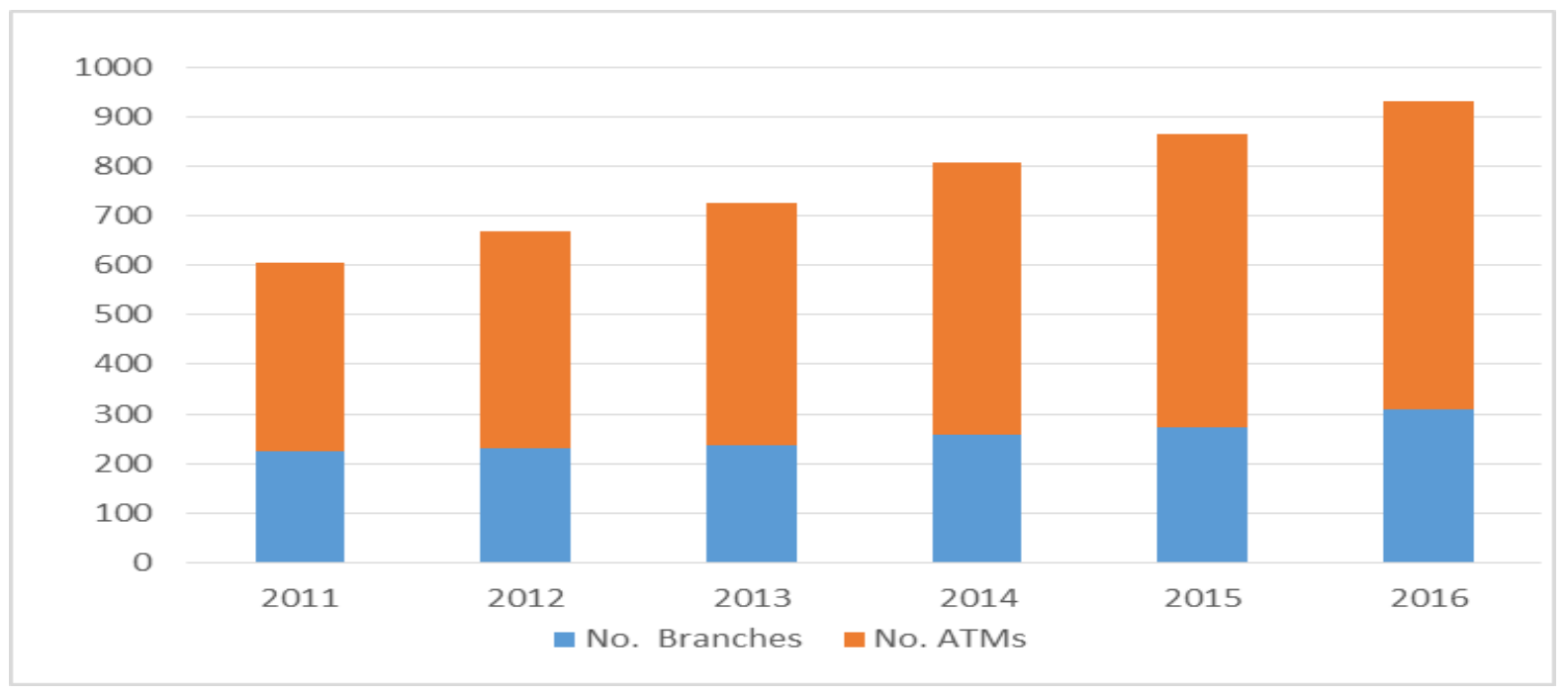

Figure 1. The development in banks branches and ATMs in Palestine

2.1.3 The bank branches distribution between large cities and rural areas in the west bank as of 2016 were 73 in small cities and villages, and 179 branches and offices in the large cities. In the last two years there is a significant spread for the banks penetration in the small cities and villages that is the PMA encouraged the banks to open more branches out the large cities.

2.1.4 The number of ATMs per 100000 adults was 15.3 ATMs, where the commercial bank branches per 100000 adults was 9.9 branches as of 2011, World Bank (2017). Where the number of ATMs per 100000 was 18.2 ATMs, and 9 branches per 100,000 as of 2016.

2.1.5 Point of sales (POSs) increased from 3685 to 6253 from 2011 to 2016, respectively. Furthermore, Credit Card issuance increased from 47046 to 118076 cards from 2011 to 2016, respectively. In addition to increased debit cards from 354352 to 547019 cards from 2011 to 2016, PMA (2017), ATM withdrawal cards indicated an increase from 101728 to 189414 from 2011 to 2015. Figure (2) presents the increases in electronic cards payments from 2011 to 2016. In Lebanon, the POS consisted of 32313 POS, where is 64349 in Egypt by 2015. 


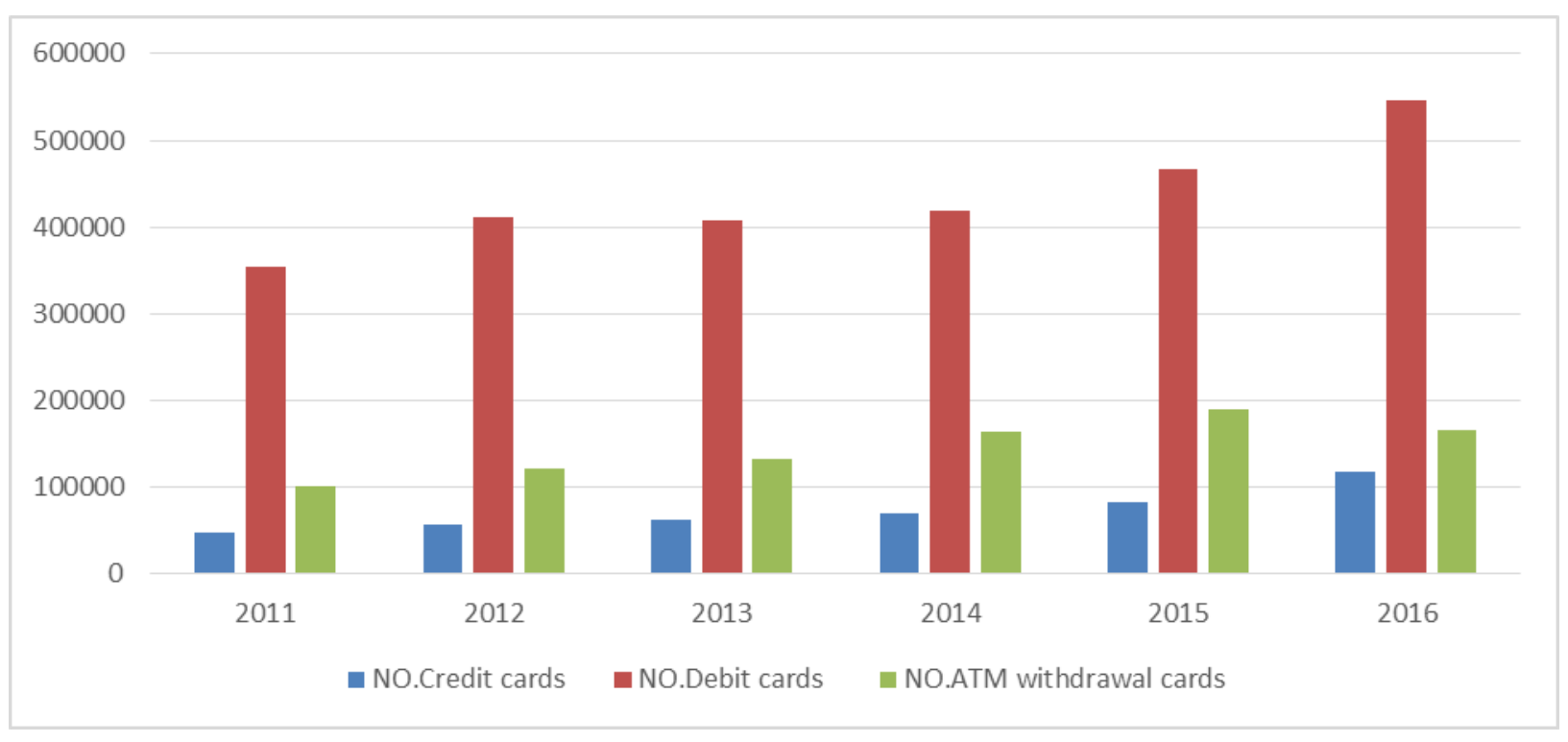

Figure 2. The development in the Electronic Cards Payment in Palestine

2.1.6 As a result of the penetration policy, banks have issued instructions facilitating the opening of a basic account for each citizen, and ATM services helped improve the financial inclusion indicators in Palestine.

2.1.7 Money exchangers increased in the last 6 years and peaked at 275 in 2016. The number of exchangers operating as a company is 224, whereas 51 are individual firms in 2016.

\subsection{The Usage of Banking Services}

2.2.1 The financial inclusion indicators in Palestine as the Global Financial Inclusion Database 2014, indicates that $24.2 \%$ from all adults have an account at formal financial institutions, while this indicator in MENA was $14.2 \%$. Further, the saving indicator was $5.1 \%$ that have saved at the formal financial institutions while in the MENA was $4 \%$ have saved in the formal financial institutions. Moreover, the borrowed indicator was $4.2 \%$, where in MENA was 5.6\% borrowed from the formal financial institutions, World Bank (2015).

2.2.2 The number of the deposits accounts was developed from 2545459 as in 2011 to 3098 994 as in 2016. This development is as a results of the PMA regulations to enhancing the financial inclusion indicators in Palestine. This development is presented in figure (3). 


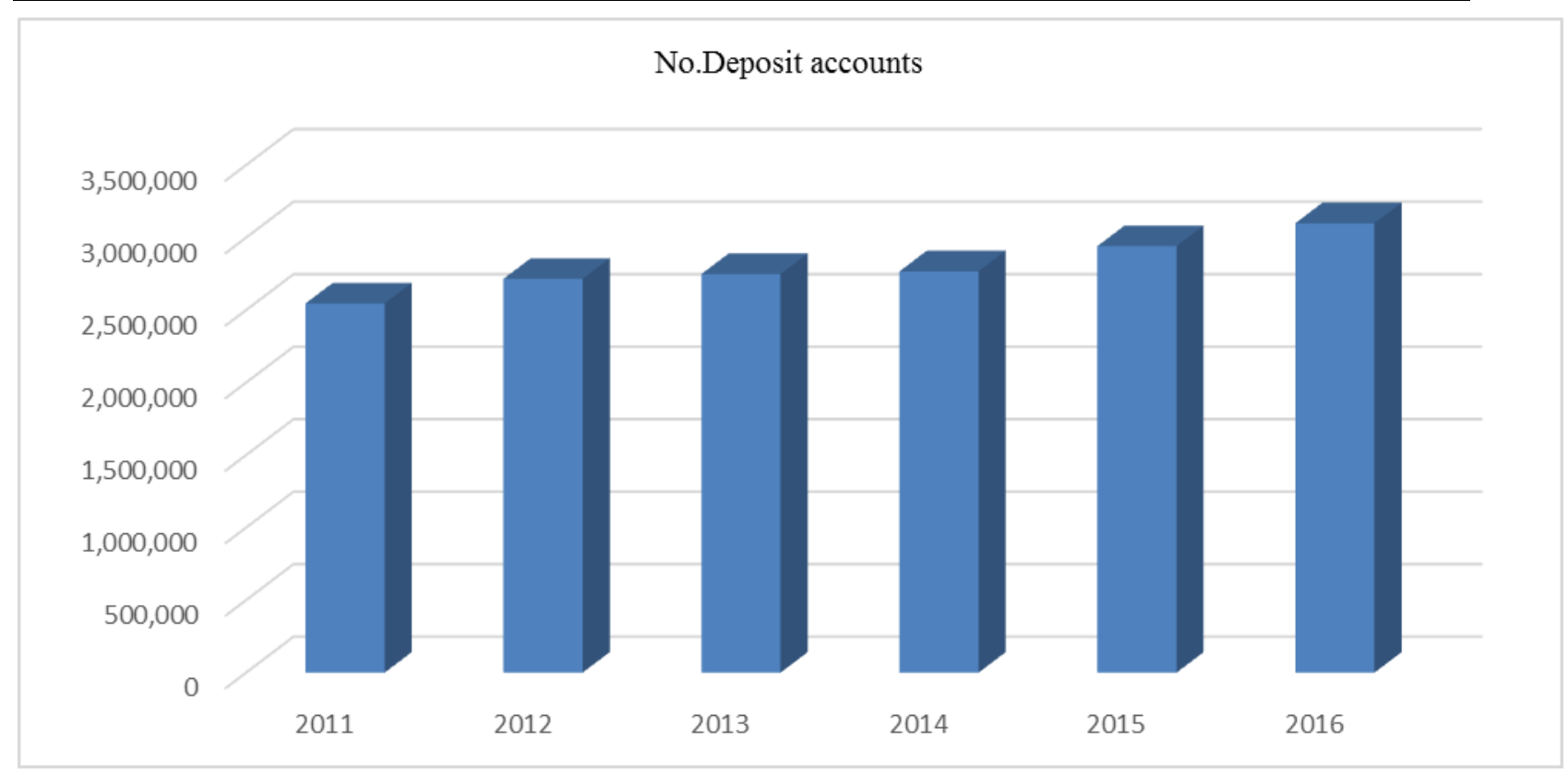

Figure 3. The development in No. of Deposits Accounts

2.2.3 The economy of Palestine experienced chronic shortage in terms of facilities and credit despite abundant deposits, which rose from 6972.5 to 10595.7 million US\$ from 2011 to 2016. However, total grants increased from 3552.7 to 6865.9 million US\$ from 2011 to 2016. These deposit and credit developments in the Palestinian economy are presented in Figure (4).

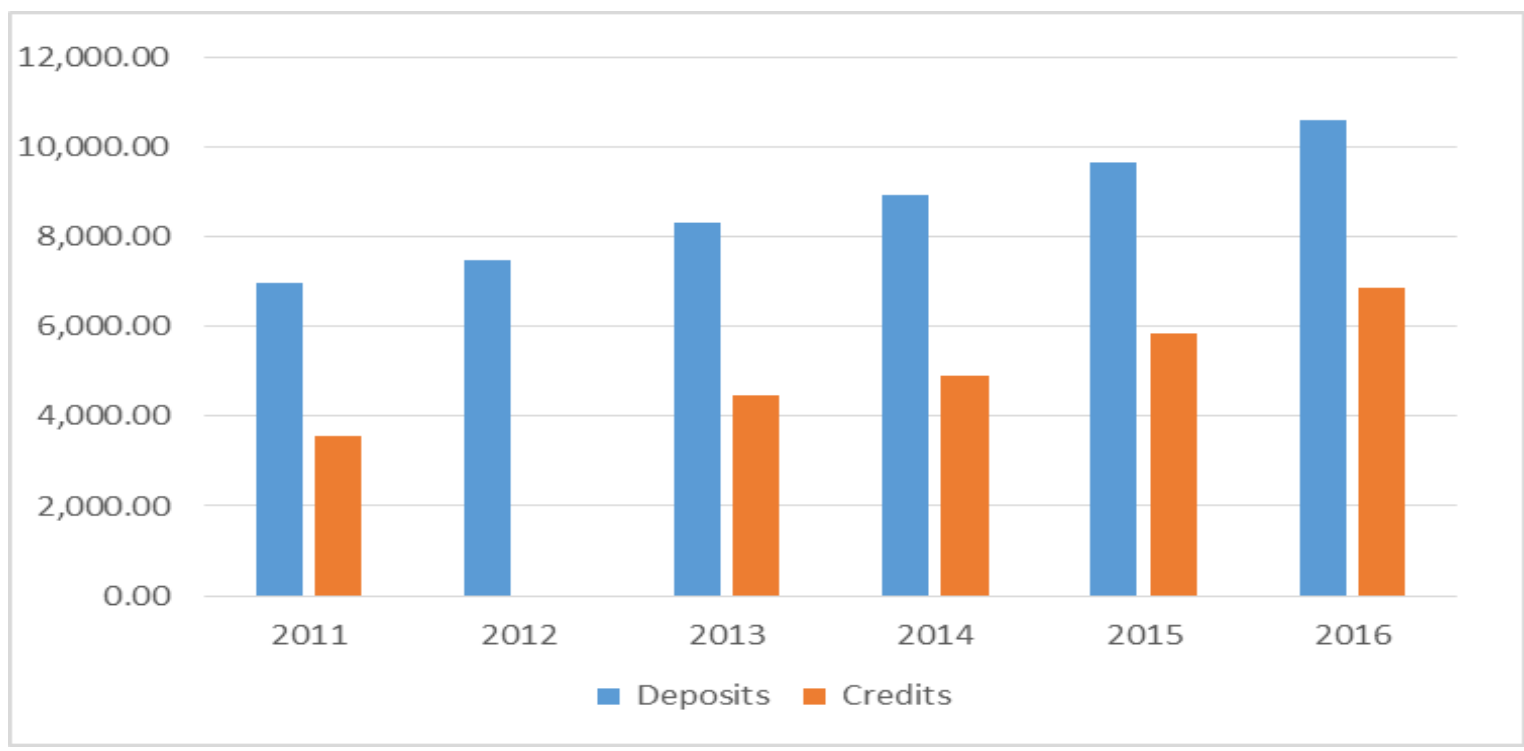

Figure 4. The development in the individuals Deposits and Credits in million US\$

2.2.4 Six lending institutions were granted initial licenses to offer services in Palestine, whereas thirteen lending institutions and programs on specialized lending in Palestine have 


\section{Macrothink}

Business and Economic Research ISSN 2162-4860 2017, Vol. 7, No. 1

72 branches. The six institutions are licensed by the PMA granted 51952 loans. From more than 51589 borrowers with a debt of 136.7 million US\$ as of 2015, 40\% are females. Majority of the loans went to the housing and mortgage sectors with $28 \%$, followed by general trading with $24 \%$.

2.2.5 PMA is working to develop the electronic financial system to be easy and fast which leads to decrease cost and time in the banking transaction such as "BORAQ" system for the banking remittances which is developed newly. Figure (5) presents the number and amount of banking remittances development since 2011 to 2015.

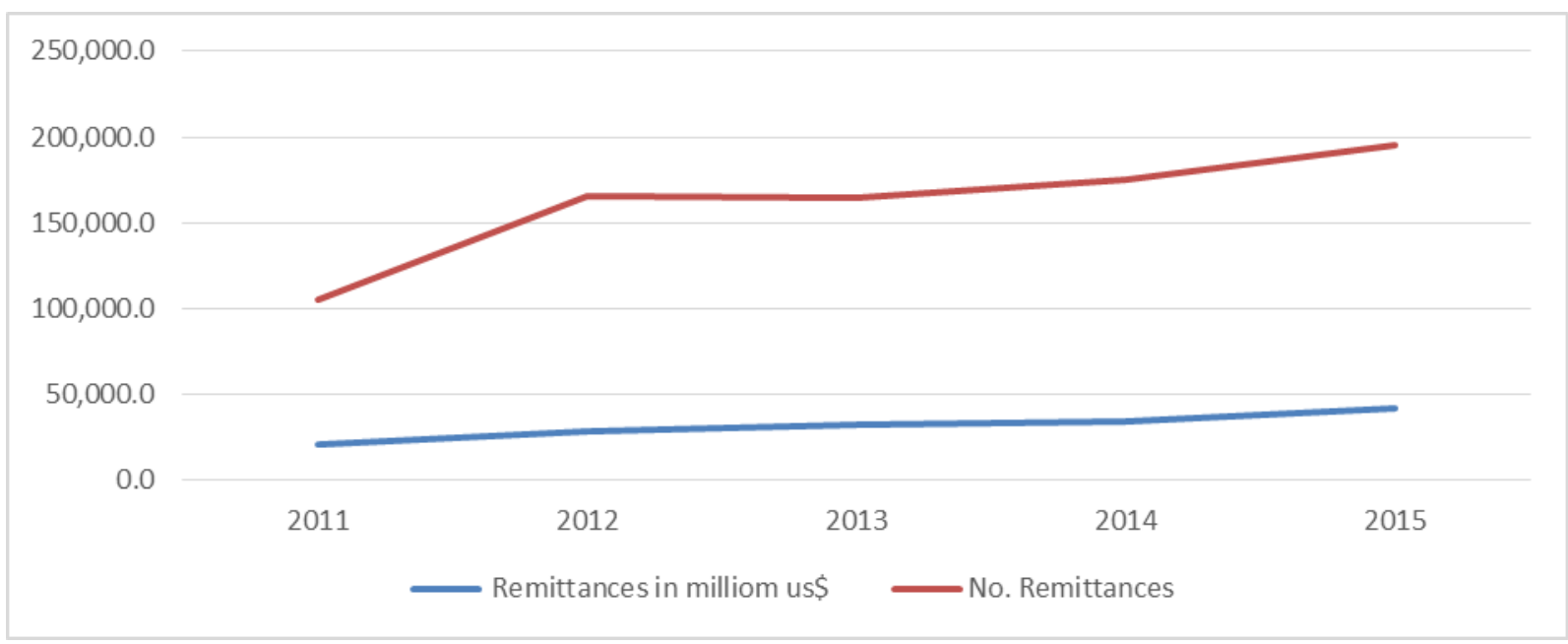

Figure 5. The development in numbers and amount in the remittances

2.2.6 The growth in the insurance sector portfolio was 158.7 million US\$ in 2013 increased to 164.8 million US\$ in 2015. The number of insurance companies in Palestine reached to 9 companies, with a total of 116 branches and 206 insurance agents, in addition to the 1,156 employees in insurance companies' branches as of 2015. Figure (6) presents some facts related to the insurance companies.

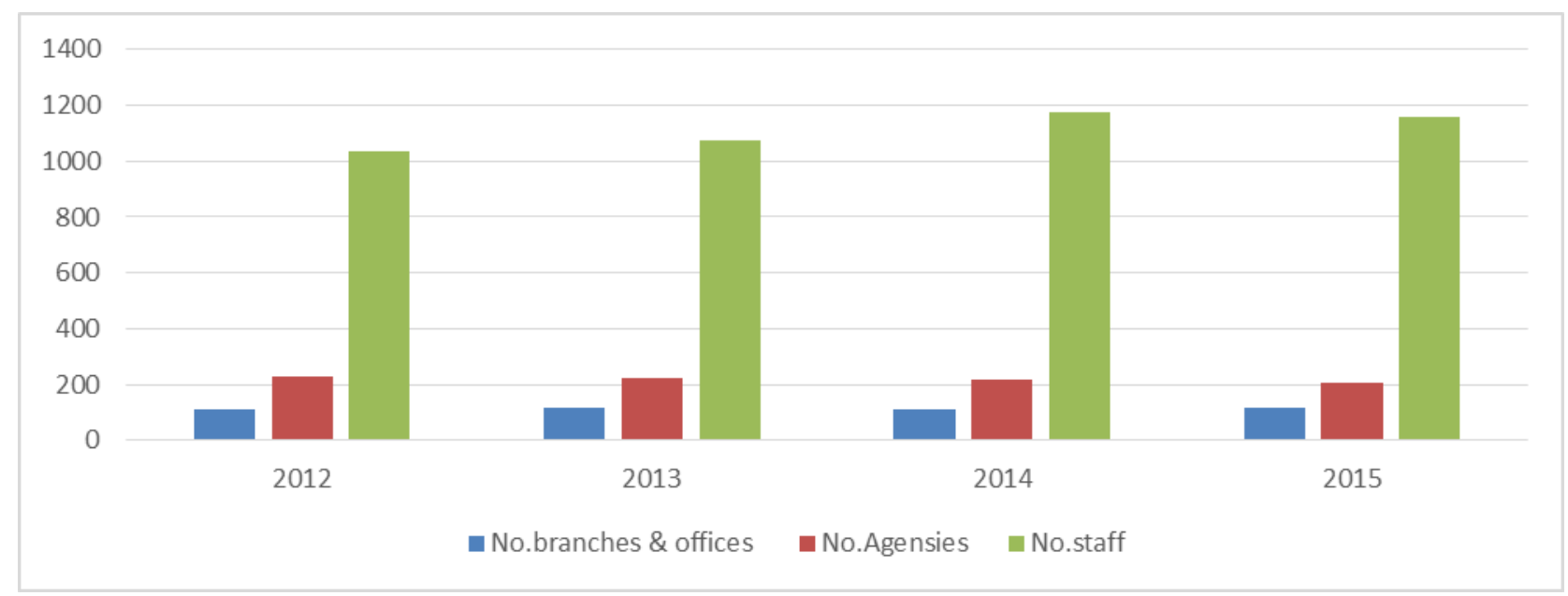

Figure 6. The changes in the insurance companies in the recent four years 


\section{$\triangle$ Macrothink}

Business and Economic Research ISSN 2162-4860 2017, Vol. 7, No. 1

2.2.7 Palestine has achieved a notable enhancement in the financial inclusion indicators when comparative with MENA region, especially the access to finance which is $24.2 \%$ age $15+$ in Palestine while in MENA 14.2\% age 15+, World Bank (2015). Furthermore, the saving and borrowing indicators are in the same rate both Palestine and MENA, in MENA the saving at formal financial institutions was $4 \%$ age $15+$ where the borrowing from formal financial institutions was $5.6 \%$ age 15+. Some countries like Jordan and Lebanon achieved remarkable development in borrowing from the formal financial institutions, where in Lebanon remarkable development was achieved in saving at formal financial institutions . While in Egypt, the indicators as whole MENA region. Table (1) shows the comparison of financial inclusion indicators between Palestine, Egypt, Lebanon and Jordan.

Table 1. Comparative in financial inclusion indicators between Palestine, and other MENA countries

\begin{tabular}{|c|c|c|c|c|}
\hline Indicators & Palestine & Egypt & Lebanon & Jordan \\
\hline No. Banks & 16 & 40 & 53 & 25 \\
\hline Branches & 274 & 3768 & 1039 & 1060 \\
\hline ATMs & 592 & 9031 & 1707 & 1488 \\
\hline POSs & 5987 & 64349 & 32313 & $28,200 *$ \\
\hline Have Account $^{1,2}$ & 24.2 & 14.1 & 46.6 & 24.6 \\
\hline Access to Finance $^{1,3}$ & 24.2 & 13.7 & 46.6 & 24.6 \\
\hline Saved $^{1,3}$ & 5.1 & 4.1 & 17.5 & 3.8 \\
\hline Borrowed $^{1,3}$ & 4.2 & 6.3 & 15.6 & 13.6 \\
\hline
\end{tabular}

Sources: central banks in Palestine, Egypt, Jordan, Lebanon and World Bank. 2015. *: 2013,

1: $\%$ age $15+$,

2: $\%$ age $15+$ have an account,

3: at/from formal financial institutions

\section{Conclusion and Recommendation}

In this paper, we focused on the development in two financial inclusion indicators, these indicators are the banking penetration and the usage of the banking services. The main obstacles in such research is the data scarcity especially in the developing countries. We used the data from the World Bank findex data base, World Bank financial inclusion publications and the PMA.

In Palestine, there is a remarkable improvement in the financial inclusion indicators especially on the banking penetration. The regulations which launched by the PMA and followed by the banks to open more branches got their targets, that's $24.2 \%$ adults have an account at the formal financial institutions where in MENA $14.2 \%$.

Despite of the remarkable improvement in the penetrations indicator, the usage indicator still in the low level which is could not help in the economic development and economic stability. 
Usage indicator need more efforts from all parts in the economic especially the supply side, which should do more in offering new services to cover adults and females needings.

We recommend to conduct more studies in the MENA region applying the empirical method on supply side since without supply institutions participations, the efforts will not be notable.

\section{References}

Akhtar, S., \& Pearce, D. (2010). Microfinance in the Arab World: The challenge of financial inclusion. World Bank

Beck, T., Demirgüc-Kunt, A., \& Honohan, P. (2009). Access to financial services: Measurement, impact, and policies. The World Bank Research Observer, 24(1), 119-145. https://doi.org/10.1093/wbro/lkn008

Bester, H., Chamberlain, D., de Koker, L., Hougaard, C., Short, R., \& Smith, A. (2008). Implementing FATF standards in developing countries and financial inclusion: Findings and guidelines. Washington, DC: FIRST Initiative, the World Bank

Bruhn, M. \& Love, I. (2009). The Economic Impact of Banking the Unbanked: Evidence from Mexico. Policy Research Working Paper 4981. The World Bank.

https://doi.org/10.1596/1813-9450-4981

Camara, N., Peña, X., \& Tuesta, D. (2014). Factors that matter for financial inclusion: Evidence from Peru. Retrieved from https://www.bbvaresearch.com

Chatain, P.-L., Herna'ndez-Coss, R., Borowik, K., \& Zerzan, A. (2008). Integrity in mobile phone financial services: Measures for mitigating risks from money laundering and terrorist financing. World Banking Working Paper 146. Washington, DC: The World Bank

Chatain, P.-L., Zerzan, A., Noor, W., Dannaoui, N., \& de Koker, L. (2011). Protecting mobile money against financial crimes: Global policy challenges and solutions. Washington, DC: The World Bank. https://doi.org/10.1596/978-0-8213-8669-9

Demirgüç-Kunt, A., \& Klapper, L. F. (2012). Financial inclusion in Africa: An Overview. Policy research working paper 6088. World Bank. https://doi.org/10.1596/1813-9450-6088

Demirgüc-Kunt, A., Beck, T., \& Honohan, P. (2008). Finance for all? Policies and pitfalls in expanding access. Washington, DC: The World Bank.

Dittus, P., \& Klein, M. (2011). On harnessing the potential of financial inclusion. BIS Monetary and Economic Department Working Paper No. 347. Basel: BIS.

Ellison, A., Whyley, C., \& Forster, R. (2010). Realising banking inclusion: The achievements and challenges. London: HM Treasury Financial Inclusion Task Force.

Gandhi, M. M. (2013). Financial inclusion: Indian initiatives in the global perspective. IOSR Journal of Economic and Finance (IOSR-JEF), 2(2), 27-40.

https://doi.org/10.9790/5933-0222740

Kumar, B., \& Mohanty, B. (2011). Financial Inclusion and Inclusive Development in SAARC 


\section{Macrothink}

Business and Economic Research ISSN 2162-4860 2017, Vol. 7, No. 1

Countries with Special Reference to India. Vilakshan: The XIMB Journal of Management, $8(2)$.

Malik, R., \& Yadav, S. (2014). Financial inclusion in Indi: An appraisal. International Journal of Research (IJR), 1(4), 593-602.

Pearce, D. (2011). Financial inclusion in the Middle East and North Africa: Analyses and roadmap recommendations. World Bank. https://doi.org/10.1596/1813-9450-5610

Pickens, M. (2009). Window on the unbanked: Mobile money in the Philippines. CGAP brief. Washington, DC: CGAP.

Pickens, M., Porteous, D., \& Rotman, S. (2009). Scenarios for branchless banking. Focus Note 57. Washington, DC: CGAP

Sarma, M. (2008). Index of Financial Inclusion. Retrieved from http://icrier.org/publications/working-papers/.

Sarma, M., \& Jesim, P. (2011). Financial inclusion and development. Journal of International Development, 23, 613-628. https://doi.org/10.1002/jid.1698

Wang, X. H., Shihadeh, F. H. (2015). Financial Inclusion: Policies, Status, and Challenges in Palestine. International Journal of Economics and Finance, 7(8), 196-207.

https://doi.org/10.5539/ijef.v7n8p196

\section{Websites}

Association Banks in Palestine website: http://www.abp.ps

Association of Banks in Jordan website: http://www.abj.org.jo

Central Bank of Jordan website: http://www.cbj.gov.jo

Central bank of Lebanon website: http://www.bdl.gov.lb

Central bank of Egypt website: http://www.cbe.org.eg

Consultative Group to Assist the Poor website: http://www.cgap.org

International Monetary Fund website: http://www.imf.org

Palestine Monetary Authority website: http://www.pma.ps

Palestinian Central Bureau of Statistics website: http://www.pcbs.gov.ps

Palestine exchange statistics website: http://www.pex.ps

Palestine Capital Market Authority website: http://www.pcma.ps

World Bank website: http://www.World bank.org

\section{Copyright Disclaimer}

Copyright for this article is retained by the author(s), with first publication rights granted to the journal.

This is an open-access article distributed under the terms and conditions of the Creative Commons Attribution license (http://creativecommons.org/licenses/by/3.0/). 